\title{
Antibacterial Application of Novel Mixed-Ligand Dithiocarbamate Complexes of Nickel (II)
}

\author{
Anthony Chinonso Ekennia \\ Department of Chemistry, University of Ibadan, Ibadan. Nigeria.
}

\begin{abstract}
Nine stable mixed ligand dithiocarbamate complexes of Nickel (II) ion were prepared. The complexes were characterized with electronic spectroscopy, infrared spectroscopy, conductance measurement, melting point and percentage metal analysis. Resulting analytical data gave credence to the assignment of a tentative square planar geometry to all the complexes. The complexes were proposed to have a general formulae of $[\mathrm{Ni}(\mathrm{Sal})(\mathrm{Rdtc})]$, where Sal $=$ salicylaldehyde; $R=$ dibenzylamine $\left(\mathrm{Bz}_{2} \mathrm{NH}\right)$, methylphenylamine (MePhNH),pyrrolidineamine(pyrrolNH),piperidineamine(piperNH), morpholineamine(Morp NH), anilineamine(AnilNH), para-chloroanilineamine(p-ClAnilNH), toludineamine(TolNH) and anisidineamine(AnisNH); and dtc = dithiocarbamate anion. The metal complexes were screened against six different bacteria strain using Agar diffusion method. The antibacterial studies reveal that the metal complexes exhibit broad spectrum antibacterial activity against Escherichia coli, Staphylococcus aureus, Klebsiella oxytoca and Pseudomonas aureginosa with inhibitory range of 10.5. - 20.0mm.
\end{abstract}

Keywords: Aromatic dithiocarbamate, Salicylaldehyde, Antibacterial studies and Nickel ion.

\section{Introduction}

Dithiocarbamates are versatile compounds with wide range of chemistry. An extremely large number of dithiocarbamate complexes with transition and non transition metal ions have been reported (Dawood et al.2009; Daniel et al.2009 and Sarwar et al.2007). Compounds with dithiocarbamate moiety have attracted attention because of their potential biological activity (Leka et al. 2006). Their metal complexes present striking structural features and have diversified applications, such as high pressure lubricants, fungicides, pesticides, and accelerators used in vulcanization (Beer et al.2001).

There has been growing interest in the formation of mixed ligands chelates involving ligands containing different functional groups and transition metals of different oxidation states (Samus et al 2006 and Manov et al.2004). Coordination compounds with mixed ligands are of considerable importance in the field of metalloenzymes and are known to possess various biological activities (Rai et al.2005). Hence a large number of mixed ligand complexes with various transition metals are known (Mahapatra et al.1986 and Rai et al.2006).

As a continuation of our research on mixed ligand complexes of dithiocarbamate moiety with salicylaldehyde ( Ekennia and Odola, 2013), we report herein, the synthesis, characterization and antibacterial application of nine mixed ligand complexes of aryl dithiocarbamate and salicylaldehyde moiety with the aim of producing lead compounds for the production of effective and more selective bactericides.

\subsection{Reagents}

\section{Experimentation}

Hydrated nickel(II) chloride, carbon disulfide, sodium hydroxide, dibenzylamine, methylphenylamine, pyrrolidineamine, piperidineamine, morpholineamine, anilineamine, para-chloroanilineamine, toludineamine and anisidineamine were bought from Aldrich and Sigma Co. and British Drug House and used as supplied.

\subsection{General Preparation of mixed ligand complexes}

The complexes were prepared according to literature (Ekennia and Odola, 2013). Equimolar concentration of the dithiocarbamate, metal ion and salicylaldehyde moiety was added to an ethanolic solution and refluxed for 3 hours. The resulting precipitate was filtered under vacuum, washed with diethylether and stored under silica gel in desiccator. 
<smiles>CN(O[Na])c1cccc(N(C)C(=S)[S-])c1</smiles>

Fig 1.0: Synthesis of N-methyl-N-phenyl-dithiocarbamate<smiles>CN(C(=S)[S-])c1ccccc1</smiles><smiles>CN(C1=S2CC(O1)S[N+]21C=Cc2ccccc2O1)c1ccccc1</smiles>

Fig 1.1: Diagrammatic presentation of mechanism of reaction of Ni(Sal)(MePhdtc)

\subsection{Physical measurements}

The experimental percentage nickel content of the complexes was determined by chelatometric titration using murexide as an indicator. Electronic spectra were obtained using Genesys 10 UV Spectrophotometer. Infrared spectra were obtained using Buck 500 model spectrophotometer. Electrolytic conductivities of $1 \times 10^{-3}$ M solution of the complexes in DMF were determined using Hanna conductivity meter model H19991300.

\subsection{Antibacterial screening}

The in vitro evaluation of antibacterial activity was performed using the agar diffusion method. Three gram negative bacteria (Klebsiella oxytoea, Pseudomonas aureginosa, Escherichia coli) and three gram positive bacteria (Bacillus cereus, Proteus mirabilis and Staphylococcus aureus) were resuscitated from a nutrient slope and grown in nutrient broth at $37^{\circ} \mathrm{C}$ for 24 hours. The surface of a petri dish was uniformly inoculated with 0.2 $\mathrm{ml}$ of 24-hour old test bacteria culture. Using a sterile cork borer, $7 \mathrm{~mm}$ wells were bored into the agar. Then 10 $\mathrm{mg} / \mathrm{ml}$ solution of each test compounds in DMSO was added to the well bored. The plates were kept after inoculation at $37^{\circ} \mathrm{C}$ for 24 hours, after which the inhibitory zone (in $\mathrm{mm}$ ) were taken as a measure of antibacterial activity.

\section{$3.1\left[\mathrm{Ni}(\mathrm{Sal})\left(\mathrm{Bz}_{2} \mathrm{dtc}\right)\right]$}

\section{Results And Discussion}

The compound was obtained as light green solid and re-crystalized in hot ethanolic solution.

Formulae mass: $452.23 \mathrm{~g}$. Yield: $61 \%$. M.P/D.T. $=* 237^{\circ} \mathrm{C} . \%$ Ni experimental $($ Calculated $)=12.98(13.00)$. $\Lambda \mathrm{m}=13.00 \Omega^{-1} \mathrm{~cm}^{2} \mathrm{~mol}^{-1}$. Selected IR peaks, $\mathrm{v}\left(\mathrm{cm}^{-1}\right): 1653(\mathrm{vC}=\mathrm{O}), 1529(\mathrm{vC}=\mathrm{N}), 1229(\mathrm{vC}-\mathrm{O}), 533(\mathrm{Ni}-\mathrm{O})$ and $321(\mathrm{Ni}-\mathrm{S})$. Electronic spectra(e) $\lambda \max (\mathrm{kK}): 16.02(100), 24.80(200), 25.78\left(1 \times 10^{5}\right)$ and $39.58\left(1 \times 10^{5}\right)$.

\section{2 [Ni(Sal)(MePhdtc)]}

The compound was obtained as a dark green solid and recrystalized from hot ethanolic solution. Formulae mass: $362.11 \mathrm{~g}$. Yeild:97\%. M.P/D.T: $* 200{ }^{\circ} \mathrm{C}$. \%Ni(Cal):16.21(16.32). $\Lambda \mathrm{m}=17.00 \Omega^{-1} \mathrm{~cm}^{2} \mathrm{~mol}^{-1}$. Selected IR peaks, $\mathrm{v}\left(\mathrm{cm}^{-1}\right): 1624(\mathrm{vC}=\mathrm{O}), 1524(\mathrm{vC}=\mathrm{N}), 1201(\mathrm{vC}-\mathrm{O}), 553(\mathrm{Ni}-\mathrm{O})$ and $328(\mathrm{Ni}-\mathrm{S})$. Electronic $\operatorname{spectra}(\varepsilon) \lambda \max (\mathrm{kK}): 16.15(100), 23.70(200), 43.79\left(1 \times 10^{5}\right)$ and $50.87\left(1 \times 10^{5}\right)$. 


\section{$3.3[\mathrm{Ni}(\mathrm{Sal})($ Pyrroldte)]}

The compound was obtained as a dark green solid and recrystalized from hot ethanolic solution. Formulae mass: $362.11 \mathrm{~g}$. Yeild: $97 \%$. M.P/D.T: $* 200{ }^{\circ} \mathrm{C} . \quad \% \mathrm{Ni}(\mathrm{Cal}): 16.21(16.32) . \Lambda \mathrm{m}=17.00 \Omega^{-1} \mathrm{~cm}^{2} \mathrm{~mol}^{-1}$. Selected IR peaks, $\mathrm{v}\left(\mathrm{cm}^{-1}\right): 1624(\mathrm{vC}=\mathrm{O}), 1524(\mathrm{vC}=\mathrm{N}), 1201(\mathrm{vC}-\mathrm{O}), 553(\mathrm{Ni}-\mathrm{O})$ and $328(\mathrm{Ni}-\mathrm{S})$. Electronic $\operatorname{spectra}(\varepsilon) \lambda \max (\mathrm{kK}): 16.15(100), 23.70(200), 43.79\left(1 \times 10^{5}\right)$ and $50.87\left(1 \times 10^{5}\right)$.

\section{$3.4[\mathrm{Ni}(\mathrm{Sal})($ Pipdtc) $]$}

The compound was obtained as a Light green solid and recrystalized from hot ethanolic solution. Formulae mass: $339.10 \mathrm{~g}$. Yeild:72\%. M.P/D.T: $* 202{ }^{\circ} \mathrm{C}$. \% Ni(Cal): $16.90(17.31) . \Lambda \mathrm{m}=22.00 \Omega^{-1} \mathrm{~cm}^{2} \mathrm{~mol}^{-1}$. Selected IR peaks, $\mathrm{v}\left(\mathrm{cm}^{-1}\right): 1647(\mathrm{vC}=\mathrm{O}), 1529(\mathrm{vC}=\mathrm{N}), 1239(\mathrm{vC}-\mathrm{O}), 532(\mathrm{Ni}-\mathrm{O})$ and $321(\mathrm{Ni}-\mathrm{S})$. Electronic $\operatorname{spectra}(\varepsilon) \lambda \max (\mathrm{kK}): 15.89(100), 24.24(200), 31.38\left(1 \times 10^{5}\right)$ and $42.54\left(1 \times 10^{5}\right)$.

\section{5 [Ni(Sal)(Morphdtc)]}

The compound was obtained as a lemon green solid and recrystalized from hot ethanolic solution. Formulae mass: $342.07 \mathrm{~g}$. Yeild: $76 \%$. M.P/D.T: $* 218^{\circ} \mathrm{C} . \quad \% \mathbf{N i}(\mathrm{Cal}): 17.06(17.16) . \quad \Lambda \mathrm{m}=22.00 \Omega^{-1} \mathrm{~cm}^{2} \mathrm{~mol}^{-1}$.

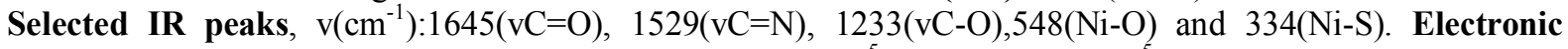
$\operatorname{spectra}(\varepsilon) \lambda \max (\mathrm{kK}): 15.16(100), 24.61(200), 27.01\left(1 \times 10^{5}\right)$ and $41.38\left(1 \times 10^{5}\right)$.

\section{$3.6[\mathrm{Ni}(\mathrm{Sal})($ Anildtc) $]$}

The compound was obtained as a dark green solid and recrystalized from hot ethanolic solution. Formulae mass: $348.08 \mathrm{~g}$. Yeild:30\%. M.P/D.T:*300 ${ }^{\circ} \mathrm{C}$. \%Ni(Cal):16.76(16.87). $\Lambda \mathrm{m}=27.00 \Omega^{-1} \mathrm{~cm}^{2} \mathrm{~mol}^{-1}$.

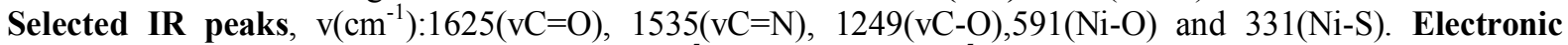
$\operatorname{spectra}(\varepsilon) \lambda \max (\mathrm{kK}): 16.99(100), 25.81\left(1 \times 10^{5}\right)$ and $48.19\left(1 \times 10^{5}\right)$.

\section{7 [Ni(Sal)(pClAnildtc)]}

The compound was obtained as a light green solid and recrystalized from hot ethanolic solution. Formulae mass: $382.52 \mathrm{~g}$. Yeild:33\%. M.P/D.T: $* 300{ }^{\circ} \mathrm{C} . \quad \% \mathrm{Ni}(\mathrm{Cal}): 15.48(15.35) . \quad \Lambda \mathrm{m}=10.00 \Omega^{-1} \mathrm{~cm}^{2} \mathrm{~mol}^{-1}$.

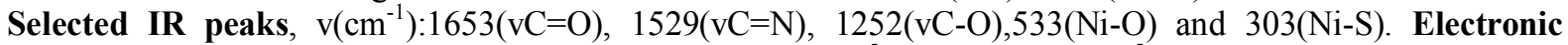
$\operatorname{spectra}(\varepsilon) \lambda \max (\mathrm{kK}): 17.47(100), 24.24(200), 36.55\left(1 \times 10^{5}\right)$ and $48.18\left(1 \times 10^{5}\right)$.

\section{8 [Ni(Sal)(Toldte)]}

The compound was obtained as a green solid and recrystalized from hot ethanolic solution. Formulae mass: $362.11 \mathrm{~g}$. Yeild: $20 \%$. M.P/D.T: $* 278{ }^{\circ} \mathrm{C} . \% \mathrm{Ni}(\mathrm{Cal}): 16.40(16.21) . \Lambda \mathrm{m}=13.00 \Omega^{-1} \mathrm{~cm}^{2} \mathrm{~mol}^{-1}$. Selected IR peaks, $\mathrm{v}\left(\mathrm{cm}^{-1}\right): 1614(\mathrm{vC}=\mathrm{O}), 1506(\mathrm{vC}=\mathrm{N}), 1205(\mathrm{vC}-\mathrm{O}), 522(\mathrm{Ni}-\mathrm{O})$ and $329(\mathrm{Ni}-\mathrm{S})$. Electronic spectra $(\varepsilon) \lambda$ $\max (\mathrm{kK}): 17.56(100), 26.00\left(1 \times 10^{5}\right)$ and $41.76\left(1 \times 10^{5}\right)$.

\section{9 [Ni(Sal)(Anisdtc)]}

The compound was obtained as a green solid and recrystalized from hot ethanolic solution. Formulae mass: $362.11 \mathrm{~g}$. Yeild:97\%. M.P/D.T: $* 200{ }^{\circ} \mathrm{C}$. \%Ni(Cal):16.21(16.32). $\Lambda \mathrm{m}=17.00 \Omega^{-1} \mathrm{~cm}^{2} \mathrm{~mol}^{-1}$. Selected IR peaks, $\mathrm{v}\left(\mathrm{cm}^{-1}\right): 1651(\mathrm{vC}=\mathrm{O}), 1529(\mathrm{vC}=\mathrm{N}), 1245(\mathrm{vC}-\mathrm{O}), 533(\mathrm{Ni}-\mathrm{O})$ and $308(\mathrm{Ni}-\mathrm{S})$. Electronic spectra $(\varepsilon) \lambda$ $\max (\mathrm{kK}): 18.27(100), 24.53(200), 25.75\left(1 \times 10^{5}\right)$ and $41.50\left(1 \times 10^{5}\right)$.

M.P/D.T = melting point $/$ decomposition temperature, $1 \mathrm{kK}=1000 \mathrm{~cm}^{-1}$.

\section{Antibacterial screening}

The complexes showed good activity against Echerichia coli, Pseudomonas aureginosa, Klebsiella oxytosa and Staphylococcus aureus. They were not active against P.mirabillis and Bacillus cereus except for $\mathrm{Ni}(\mathrm{Sal})(p \mathrm{ClAnildtc})$ and $\mathrm{Ni}(\mathrm{Sal})($ Anildtc) that had moderate activity. 


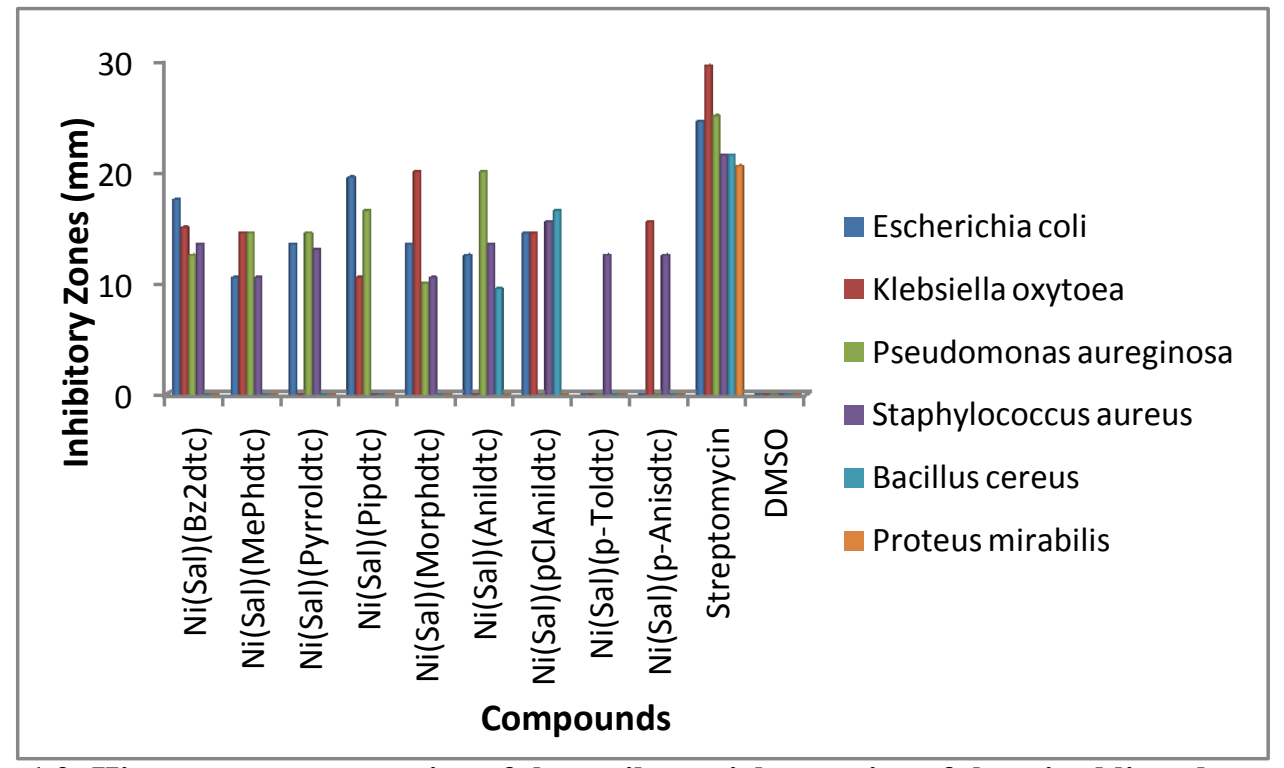

Fig 1.2: Histogram representation of the antibacterial screening of the mixed ligand complexes.

\section{Conclusion}

The assignment of a four coordinate geometry was corroborated by electronic sprectral measurements and percentage nickel content. The appearance of $\mathrm{Ni}-\mathrm{O}$ and $\mathrm{Ni}-\mathrm{S}$ bands in the infrared spectra gave proof to the coordination of the ligands to the nickel ion. The test compounds exhibited broad spectrum antibacterial activity against Escherichia coli, Pseudomonas aureginosa, Klebsiella oxytosa and Staphylococcus aureus. They were not active against Bacillis cereus and Proteus mirabilis except for $\mathrm{Ni}(\mathrm{Sal})(\mathrm{p}$-Clanildtc) and $\mathrm{Ni}(\mathrm{Sal})($ anildtc) complexes. The resistance of the pathogens towards the test compounds can be attributed to the existence of cell wall in gram positive bacteria which reduces the permeability of the test compounds, while the activity of $\mathrm{Ni}(\mathrm{Sal})(\mathrm{p}-\mathrm{Clanildtc})$ and $\mathrm{Ni}(\mathrm{Sal})($ anildtc) complexes against them can be attributed to their greater lipophilicity. The high to moderate activities showed by all the complexes proved their usefulness as potential broad spectrum antibacterial agents.

\section{References}

[1]. Daniel K G, Chen D, Orlu S, Cui Q C, Miller F R and Dou Q P. Clioquinol and pyrrolidine dithiocarbamate complex with copper to form proteasome inhibitors and apoptosis inducers in human breast cancer cells. Breast Cancer Res. 2005; 7(6):897-908

[2]. Sarwar M, Ahmad S, Ahmad S, Ali S. and Awan S A. Copper(II) complexes of pyrrolidine dithiocarbamate; Trans Met Chem. 2007;32(2):199-203.

[3]. Samus N, Gulya A, Tsapkov V, Chumakov Y and Roshu T. Coordination compounds of cobalt, nickel, copper and zinc with thiosemicarbazone and 3-phenyl-propenalsemicarbazone. Russian J. General Chem. 2006; 76(7):1100-1105.

[4]. Manov N,Mishra A K, Kaushik N K. Triphenylphosphine adduct of plati- num(IV) and palladium(II) dithiocarbama- tes complexes:a spectral and in vitro study. Spectrochim Acta. 2004; 60:3087.

[5]. Rai B K, Kumar K. and Srivastava Y P. Spectroscopic investigation and anti- fungal studies of some mixed ligand complexes of $\mathrm{Co}(\mathrm{II}), \mathrm{Ni}(\mathrm{II})$ and $\mathrm{Cu}(\mathrm{II})$ with 6-methyl-2-pyridylformamidesemica rbazone and thiosemicarbazone. Asian J Chem. 2005;17(3):17731779 .

[6]. Mahapatra B. and Panda D. Anionic mixed ligand complexes of cobalt(II) and copper(II) . J Indian Chem Soc. 1986; 63:792-793.

[7]. Rai B.K., Choudhary P., Sahi P. and Rana S. Structural characterization and antifungal studies of some mixed ligand Schiff ba se complexes with 6-bromo-2-thio-3-phenylquinazoline- 4(3H)onethiose-micarbazone. Oriental J Chem. 2006;23:1.

[8]. Dawood ZF, Hessein SH, Al-Shama,a M.A. Some complexes of Ni(II) containing mixed ligands;Sci. \& Tech. A. 2004; $21: 71-75$.

[9]. Z. F. Dawood, T. J. Mohammed and M. R. Sharif. New nickel (II) complexes with benzilbis (semicarbazone) and dithiocarbamate ligands. Proceedings of the 5th Scientific Conference, College of Veterinary Medicine, University of Mosul.Journal of Veterinary Sciences, Vol. 23, Supplement II, 2009 (135-141)

[10]. Ekennia Anthony C and Odola Adekunle J. Synthesis, physico-chemical characterization and biocidal studies of nickel (ii) mixedligand complexes of alkyl dithiocarbamate and salicylaldehyde.International journal of pharmaceutical, biological and chemical sciences, 2013, accepted manuscript I.d; 2040837151.

[11]. Leka Z.B, Leovac V.M, Lukic S, Sabo T.J, Trifunovic S.R and Katalin M.S(2006).Synthesisand physico-chemical characterization of new dithiocarbamato ligand and its complexes with copper(II), nickel(II) and Palladium(II). J. Therm Anal and Cal. 83.

[12]. Beer, P.D.; Berry, N.; Drew, M.G.B.; Fox, O.D.; Padilla-Tosta, M.E.; Patell, S. Self-assembled dithiocarbamate-copper(II) macrocycles for electrochemical anion recognition. Chem. Commun. 2001, 4, 199-200. 